ABDI: Jurnal Pengabdian dan Pemberdayaan Masyarakat ISSN: 2656-369X (Print), 2684-8570 (Online)

Volume 1 No. 2, Desember 2019

http://abdi.ppj.unp.ac.id/index.php/abdi

Email: abdi@ppj.unp.ac.id

DOI: https://doi.org/10.24036/abdi.vli2.14

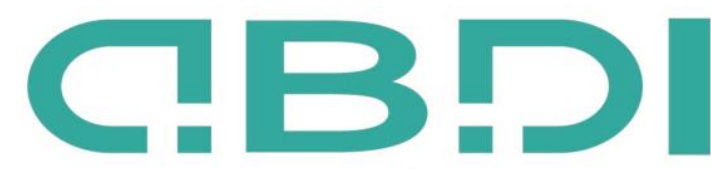

ABDI: JURNAL PENGABDIAN DAN PEMBERDAYAAN MASYARAKAT

\title{
Peluang Usaha Bagi Masyarakat Nagari Sungai Pinang untuk Pengembangan Ekowisata
}

\author{
Mira Hasti Hasmira ${ }^{1}$, Erda Fitriani ${ }^{2}$ \\ 1.2 Jurusan Sosiologi Universitas Negeri Padang
}

Email : mirahasti@ fis.unp.ac.id, erdafitriani@fis.unp.ac.id

\begin{abstract}
Abstrak
Masyarakat Nagari Sungai Pinang merupakan daerah wisata yang memiliki keindahan alam yang sangat indah. Masyarakatnya memiliki animo yang sangat tinggi untuk pengembangan ekowisata. Namun, karena kurangnya SDM, hal ini menjadi terkendala. Termasuk dalam upaya peningkatan perekonomian melalui kegiatan wisata. Tulisan ini menjelaskan tentang kegiatan pengabdian kepada masyarakat yang dilakukan dalam upaya peningkatan kualitas SDM untuk pengembangan perekonomian dalam dunia wisata. Kegiatan yang dilakukan adalah dengan melakukan sosialisasi kewirausahaan, tepatnya tentang bagaimana membaca peluang usaha. Peluang usaha yang dimaksud disesuaikan dengan situasi yang ada di Nagari Sungai Pinang. Pada akhir kegiatan ini terbentuk kepengurusan dan dua kelompok usaha yang dirasa sesuai dengan situasi yang ada di Nagari Sungai Pinang.
\end{abstract}

Kata kunci: Ekowisata, Peluang usaha, Sungai Pinang, Usaha, Wirausaha.

\section{Abstract}

Nagari Sungai Pinang is a tourist area that has beautiful natural beauty. The community has a very high interest for the development ecotoursm. However, due to lack of human resources, this has become constrained. Included in efforts to improve the economy through tourism activities. This paper explains about community service activities carried out in an effort to improve the quality of human resources for economic development in the world of tourism. The activity carried out is by conducting entrepreneurship socialization, precisely about how to read business opportunities. The business opportunity in question is adjusted to the situation in Nagari Sungai Pinang. At the end of this activity a management and two business groups were formed which were deemed appropriate to the situation in Nagari Sungai Pinang.

Keywords: Busines opportunities, Business enterpreneurship, Ecotourism, Sungai Pinang

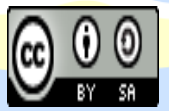




\section{Pendahuluan}

Sungai Pinang merupakan nagari di Kabupaten Pesisir Selatan. Berada di samping Mandeh yang dikenal sebagai Raja Ampat-nya Sumbar, Sungai Pinang yang dikenal sebagai perkampungan nelayan juga memiliki alam yang indah dan menawan. (Prakoso, 2015) Berdasarkan penelitian yang telah dilakukan ditemukan bahwa animo masyarakat tinggi untuk mengembangkan pariwisata di daerahnya, hanya saja mereka tidak memiliki kemampuan SDM yang cukup, hal ini salah satunya disebabkan karena tingkat pendidikan masyarakat yang masih rendah. Dengan demikian, partisipasi masyarakat dalam pengembangan pariwisata masih rendah, dan yang merasakan keuntungan dari kegiatan pariwisata hanya segelintir orang, dengan arti kata masyarakat belum merasakan efek pariwisata terutama kesejahteraan ekonomi untuk sebagian besar masyarakat. (Fitriani, 2019)

Untuk meningkatkan perekonomian masyarakat melalui pembangunan pariwisata ekologi (ekowisata) pada masyarakat Nagari Sungai Pinang, salah satu jalan yang dilakukan adalah dengan memberikan sosialisasi tentang kewirausahaan yang cocok dijalankan berbarengan dengan pengembangan ekowisata. Pengetahuan tentang kewirausahaan sangat penting dimiliki oleh masyarakat dalam rangka memulai dan mengembangkan sebuah usaha atau bisnis dalam dunia pariwisata. Apalagi dengan tingginya angka kunjungan wisatawan di kawasan ini. Di Nagari Sungai Pinang saat ini telah terdapat satu unit homestay yang bernama Ricky's Beach House dan dikelola secara profesional oleh pemiliknya yang merupakan penduduk Nagari Sungai Pinang. Jumlah wistawan yang berkunjung dan menginap di Nagari ini pada musim liburan (musim dingin) yaitu sekitar 40-60 orang wisatawan asing. Menurut Ricky jika jumlah wisatawan tidak tertampung di penginapannya. (Fitriani, 2018)

Pengetahuan kewirausahaan mendukung nilai-nilai wirausaha bagi seseorang, sehingga diharapkan menumbuhkan jiwa usaha untuk berwirausaha. Sikap dan motivasi berwirausaha sangat dibutuhkan bagi yang ingin berwirausaha agar mampu mengidentifikasi peluang usaha, kemudian mendayagunakan peluang usaha untuk menciptakan peluang kerja baru. Pengetahuan seseorang tentang kewirausahaan diharapkan akan membentuk kecenderungan mereka untuk membuka usaha baru di masa mendatang. (Sofia, 2017)

Kemampuan berwirausaha di dasari atas sebuah kepentingan membaca peluang untuk pengembangan sebuah usaha, tersedianya cukup waktu untuk mengimprofisasikan kreatifitas usahanya, dan dorongan yang kuat dalam menguasai pasar. Sehingga dalam hal ini diperlukan konsep-konsep dasar berwirausaha agar tidak terjebak dalam kemacetan improfisasi.(Alfianto, 2013).

Oleh karena itu, dalam sosialisasi kewirausahaan yang dilakukan lebih mengarah pada bagaimana membaca peluang usaha terutama disesuaikan dengan situasi yang ada dan pelatihanpelatihan yang sudah diberikan kepada masyarakat di Nagari Sungai Pinang dalam kegiatan pengabdian kepada masyarakat ini.

Peluang usaha merupakan situasi yang memungkinkan terciptanya kerangka berfikir baru dalam rangka mengkreasi dan mengombinasikan sumber daya untuk menghasilkan profit.Wirausaha dapat menciptakan peluang usaha bagi dirinya dengan memperhatikan lingkungan sekitarnya.

Wirausaha adalah seseorang yang dengan gigih berusaha untuk menjalankan sesuatu kegiatan bisnis dengan tujuan untuk mencapai hasil yang dapat dibanggakan. karakter seorang wirausaha Berani mengambil risiko, Bijaksana dalam membuat keputusan, Pandai melihat kesempatan yang terbuka, Berkemampuan menjadi manajer yang baik

Peluang usaha merupakan situasi yang memungkinkan terciptanya kerangka berfikir baru dalam rangka mengkreasi dan mengombinasikan sumber daya untuk menghasilkan profit. Wirausaha dapat menciptakan peluang usaha bagi dirinya dengan memperhatikan lingkungan sekitarnya. Salah satu cara mengenal usaha yang akan ditekuni adalah dengan cara menilai kekuatan yang ada pada diri sendiri. Kegiatan itu meliputi aspek ; (1) Minat, yaitu bidang usaha yang didasari atas minat akan lebih cenderung menyenangkan dari pada didasari oleh ikut-ikutan melihat usaha orang lain. (2) Pengetahuan, yaitu pengetahuan juga menentukan dalam pilihan usaha yang akan ditekuni seperti pengetahuan dalam pengurusan usaha, keuangan, promosi, melayani pelanggan, memasarkan dan sebagainya. (3) Kemahiran, yaitu memiliki suatu kemahiran atau keahlian tertentu dapat menjadi asset dalam memulai suatu usaha. Keahlian ini bisa juga diperoleh melalui jenjang pendidikan, pelatihan dan sebagainya. (4) Pengalaman, yaitu dengan memiliki pengalaman, seorang usahawan lebih terampil 
dalam mengurususahanya. Dengan banyaknya pengalaman yang telah diterima semasa hidupnya tentu mendapatkan kebaikan-kebaikan dalam menjalankan usaha yang dijalankan.(5) Modal, yaitu merupakan aspek penting juga dalam memulai usaha baru. Jumlah modal menentukan jenis usaha yang akan dijalankan. Dengan modal kecil tentunya tidak bisa menjalankan usaha yang memerlukan modal yang besar. (Buang, 2013)

\section{Metode Pelaksanaan}

Sosialisasi kewirausahaan bersifat transfer of knowledge. Kegiatan dilakukan menggunakana metode diskusi dan partispasi yang melibatkan perangkat pemerintah nagari, masyarakat, pemuda, dan ibu-ibu di Nagari Sungai Pinang. Mereka telibat aktif dalam kegiatan tersebut. Pendekatan yang digunakan dalam setiap kegiatan adalah pendekatan bottom up, yakni pendekatan yang bersumber dari bawah. Dengan kata lain, kegiatan- kegiatan yang dilaksanakan akan disesuaikan dengan permintaan dan kebutuhan masyarakat. Oleh karena itu, hasil dari kegiatan ini dapat memberi manfaat pada masyarakat secara masksimal. Pendekatan yang digunakan dalam setiap kegiatan adalah pendekatan bottom up, yakni pendekatan yang bersumber dari bawah. Dengan kata lain, kegiatan- kegiatan yang dilaksanakan akan disesuaikan dengan permintaan dan kebutuhan masyarakat. Oleh karena itu, hasil dari kegiatan ini dapat memberi manfaat pada masyarakat secara masksimal. Pendekatan yang dilakukan bersifat bottom up, artinya kegiatan yang dikembangkan tidak hanya didasarkan pada ide dari tim pemberdayaan melainkan sesuai dengan kebutuhan masyarakat tempatan (Fatimah, 2017). Setiap kegiatan juga ditekankan untuk membangun karakter masyarakat menuju desa wisata dengan konsep sustainable tourism.

Metode yang digunakan dalam kegiatan pengabdian ini adalah metode partisipatif dan capacty building. Kelompok sasaran pengabdian adalah ibu-ibu PKK, dan Kelompok Sadar Wisata (PokDarWis). Kegiatan ini merupakan salah satu dari rangkaian kegiatan dalam Pengabdian Masyarakat Program Nagari Binaan dengan judul kegiatan Pemberdayaan Masyarakat untuk Pengembangan Ekowisata di Nagari Sungai Pinang, tapatnya kegiatan tahun 1 dari 3 tahun yang direncanakan. Kegiatan ini dilakukan pada hari Minggu, tanggal 22 September 2019 di Kantor Wali Nagari Sungai Pinang. Langkah-langkah kegiatan dalam 1 tahun pertama adalah sebagai berikut :

1. Tim melakukan pertemuan dengan warga dan perangkat nagari untuk perencanaan Master plan ekowisata Nagari dengan melakukan FGD.

2. Tim pengabdian bersama masyarakat dan perangkat nagari merancangkan kegiatan-kegiatan yang sesuai dengan kebutuhan masyarakat dan nagari

3. Tim pengabdian bersama masyarakat dan perangkat nagari membentuk kelompok komunitas dengan menunjuk penanggung jawab dimasing- masing kelompok tersebut, misalkan kelompok sadar wisata, kelompok kerajinan, kelompok kesenian, kelompok menyulam, kelompok homestay, dll.

4. Masyarakat menjalankan kegiatan-kegiatan yang sudah direncanakan dengan bimbingan dari perangkat nagari dan tim pengabdian, dengan didampingi oleh beberapa tim pakar yang akan memberikan berbagai pengetahuan dan pelatihan, salah satu kegiatan adalah sosialisasi kewirausahaan.

5. Satu kali dalam dua minggu masyarakat melakukan evaluasi dari kegiatan yang dilakukan. Evaluasi juga dihadiri perangkat nagari dan tim pengabdian untuk melihat kelemahan dan kemajuan dari kegiatan yang sudah dilakukan.

6. Masyarakat bermusyawarah mengambil keputusan secara bersama-sama dan merancang program berikutnya sesuai dengan kebutuhan.

7. Tim menghadirkan beberapa tanaga pakar untuk memberikan transfer of knewledge sesuai dengan kebutuhan kegiatan pertahun.

Evaluasi pelaksanaan kegiatan dapat dianalisis dari aspek kognitif, afektif dan psikomotorik peserta pelatihan. Aspek kognitif terlihat dari pemahaman dari peserta dalam praktek pelatihan yang dilakukan sebelum kegiatan dan sesudah pelatihan. 


\section{Hasil dan Pembahasan}

Setelah pemaparan materi mengenai kewirausahaan terutama tentang bagaimana memahami dunia kewirausahaan dan bagaimana melihat peluang usaha yang cocok dengan lingkungan dan masyarakat di Nagari Sungai Pinang, Pesisir Selatan, dilanjutkan dengan diskusi seiring pertanyaan yang muncul dari peserta.

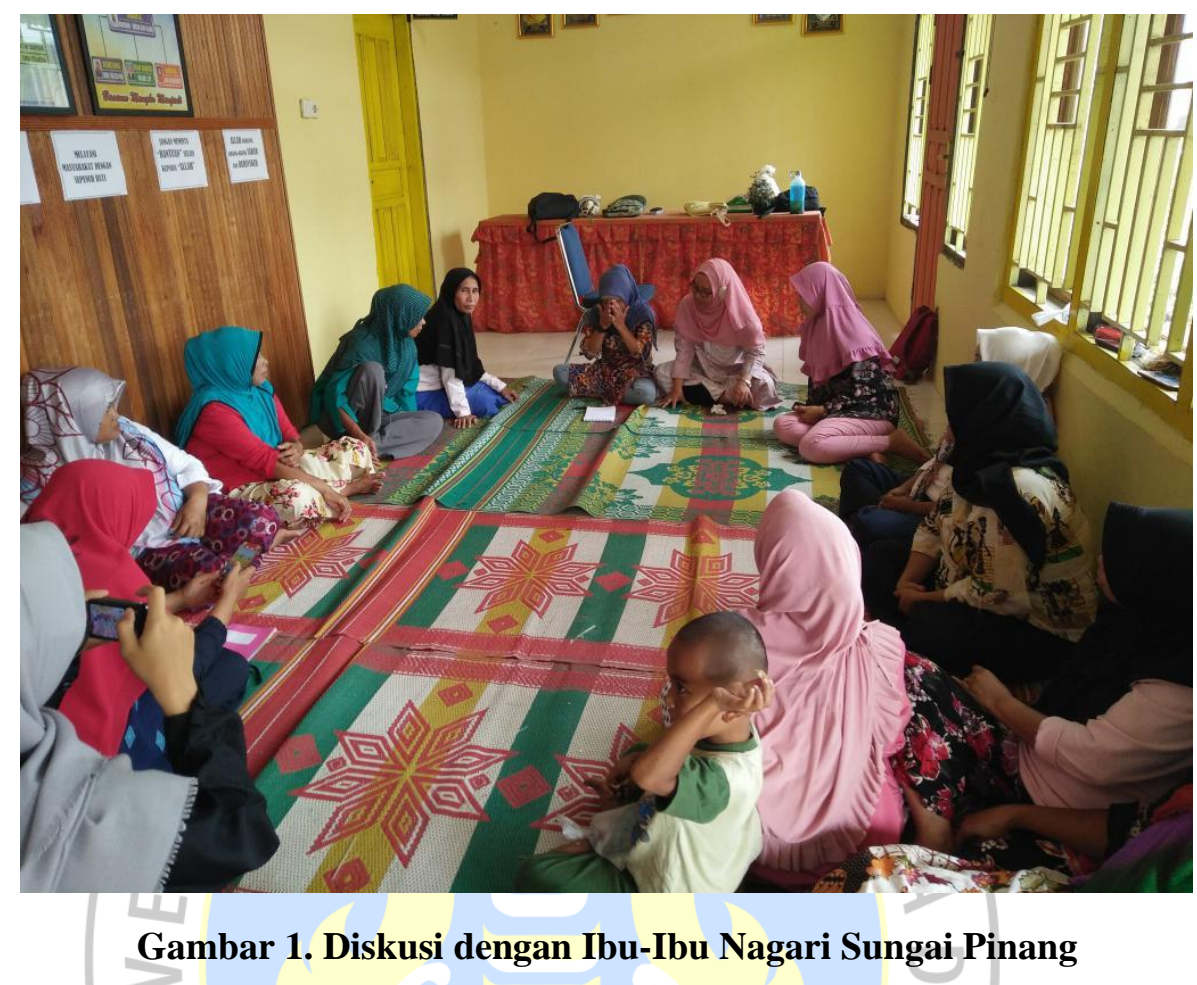

Dari diskusi yang berlangsung berdasarkan pertanyaan-pertanyaan yang muncul ketika pemaparan materi sedang berjalan dan telah selesai, ditemukan bahwa permasalahan utama yng dihadapi oleh masyarakat Nagari Sungai Pinang yang hadir pada saat kegiatan pengabdian kepada masyarakat ini berlangsung adalah masalah trust atau kepercayaan antara sesama warga untuk memulai dan jika akan menjalankan sebuah usaha bersama. Hal ini muncul karena berdasarkan kegiatan-kegiatan yang sudah pernah dilakukan warga sebelumnya, ada diantara warga yang mau menang sendiri atau tidak mau melibatkan warga lainnya. Permasalahan lain yang muncul adalah tentang kekhawatiran bagaimana me manage usaha yang ada sehingga usaha yang dijalankan bersama bisa memberikan nilai guna bagi masyarakat Nagari Sungai Pinang. Hal ini menjelaskan bahwa masyarakat tidak memiliki kemampuan dan sumber daya manusia yang memiliki pengetahuan dalam bidang manajemen usaha.

\section{Kepercayaan (trust)}

Kepercayaan antar anggota tim sangat penting untuk memualai dan melaksanakan sebuah usaha. Seperti yang dituliskan oleh Moh. Dulkiah, bahwa kunci keberhasilan suatu kerja sama sangat dipengaruhi oleh rasa saling percaya yang diangkat oleh semua pihak yang terlibat. Keberlanjutan kerja sama sangat dipengaruhi oleh ukuran tingkat kepercayaan (radius kepercayaan) yang didirikan di antara pihak-pihak yang terlibat. Kerjasama akan mudah dilakukan dan dapat bertahan lama jika membangun nilai/norma kepercayaan yang tinggi. Sebaliknya kerjasama akan mudah hancur bahkan tidak terbentuk sama sekali jika di dalamnya memiliki nilai/norma kepercayaan yang rendah. Dengan demikian tingkat kerjasama yang tinggi sangat berkaitan dengan seberapa besar nilai/norma kepercayaan yang terbentuk antara pihak- pihak yang terlibat dalam kerja sama.

Kemampuan pengusaha dalam membangun kepercayaan dan komitmen yang tercermin dalam hubungan relasional pada akhirnya menjadi kunci keberhasilanusaha. Jika hubungan saling percaya telah terbentuk, mereka akan mudah membangun kerjasama baik dalam penyediaan modal usaha, penyediaan barang, maupun pendistribusiannya. Bahkan menurut Fukuyama (1995), jika para

$$
\begin{array}{r}
\text { ABDI: Jurnal Pengabdian dan Pemberdayaan Masyarakat, Vol. } 1 \text { No. } 2 \\
\text { E-ISSN: 2684-8570| ABDI } 2019 \\
\text { Copyright` 2019, By Author }
\end{array}
$$


pengusaha menerapkan sikap saling percaya, maka mereka akan dapat menyimpan (saving) biaya pengurusan kontrak, seperti penekanan terhadap biaya transaksi, mengurangi pertikaian, dan mengurangi proses hukum jika terjadi pertikaian. Peserta kegiatan sosialisasi ditekankan untuk memahami betapa pentingnya kepercayaan (trust) antar anggota tim dalam upaya membangun dan melaksanakan usaha (bisnis).

\section{Memanage Usaha}

Berdasarkan diskusi yang berkembang ketika Kegiatan Sosialisasi Kewirausahaan berlangsung, memanage usaha lebih terarah pada diskusi mngenai pentingnya sosok pemimpin dalam tim dan bagaimana pembagian kerja dala sebuah tim kerja. Hofer dan Sandberg (dalam Hunger \& Wheelen, 2003) dalam Andi Wijayanto mengemukakan bahwa terdapat tiga faktor yang berpengaruh terhadap kinerja usaha kecil terutama untuk usaha baru. Sesuai dengan tingkat pengaruhnya, faktor-faktor tersebut adalah struktur industri, strategi bisnis, dan karakteristik wirausaha. Terdapat empat faktor karakteristik wirausaha yang berpengaruh terhadap kesuksesan usaha, yaitu: (a) mampu mengidentifikasi kesempatan bisnis potensial; (b) memiliki sense of urgency yang membuat mereka beroreintasi pada tindakan; (c) mempunyai pengetahuan terinci atas faktor-faktor kunci yang diperlukan untuk sukses dalam industri dan stamina fisik yang diperlukan untuk pekerjaannya; dan (d) mampu mencari bantuan dari pihak luar. Steinhoff \& Burgess (1993) mengemukakan bahwa keberhasilan usaha dipengaruhi oleh beberapa faktor, antara lain adalah memiliki visi dan tujuan bisnis, berani mengambil risiko dan uang, mampu menyusun perencanaan usaha, mengorganisir sumber daya, dan implementasinya, sanggup bekerja keras, mampu membangun hubungan dengan pelanggan, tenaga kerja, pemasok, dan sebagainya, dan memiliki tanggung jawab terhadap keberhasilan maupun kegagalan. (Riswanto, 2014)

Sedangkan menurut Harefa (2007) keberhasilan usaha dipengaruhi oleh karakteristik wirausahawan yaitu kecakapan pribadi dan kecakapan sosial. Kecakapan pribadi menyangkut soal bagaimana wirausahawan mengelola diri sendiri. Tiga unsur yang terpenting untuk menilai kecakapan pribadi seorang wirausahawan, yaitu: kesadaran diri, pengaturan diri, dan motivasi. Kecakapan sosial menyangkut soal bagaimana wirausahawan menangani suatu hubungan. Dua unsur kecakapan sosial seseorang adalah empati dan keterampilan sosial. Dengan kata lain keberhasilan menjadi wirausaha itu berkaitan erat dengan kecerdasan dan kecakapan emosi seseorang. Untuk menjadi wirausaha sukses diperlukan kecerdasan intrapersonal (kecakapan pribadi) dan kecerdasan interpersonal (kecakapan sosial). (Wijayanto, 2013)

Dalam penelitian yang dilakukan oleh Andi, membuktikan bahwa keberhasilan menjadi wirausaha sangat berkaitan erat dengan kecerdasan dan kecakapan emosi seseorang. Untuk menjadi wirausaha sukses diperlukan kecerdasan interpersonal (kecakapan sosial). Beberapa pelaku usaha pengasapan ikan di Krobokan yang tidak memiliki kecakapan 11 sosial kebanyakan gagal dalam menjalin hubungan dengan pemasok, pengecer dan konsumen. Hal ini berakibat pada pasokan bahan baku ikan yang menggantungkan diri pada pesaing yang memiliki jaringan dengan pemasok. Selain itu pasar yang dilayani tidak dapat berkembang sesuai dengan yang diharapkan. Meskipun jika dilihat dari faktor kesadaran diri, pengaturan diri dan motivasinya tergolong baik, namun kurangnya ketrampilan sosial membuat mereka kurang berhasil dalam mengatasi kendala bahan baku dan pengembangan pasar. Pada akhir kegiatan, ditetapkan bahwa Ibu Mailinda, S.Pd dipilih dan ditetapkan sebagai Ketua Kelompok Usaha Ibu-Ibu di Nagari Sungai Pinang. Kemudian dibentuk 2 kelompok usaha yang masing-masing bergerak dibidang kuliner nugget ayam dan kelompok usaha dibidang kerajinan sulam bayang.

\section{Kesimpulan}

Untuk meningkatkan perekenomian di bidang pariwisata di Nagari Sungai Pinang, Kabupaten Pesisir Selatan perlu dilakukan sosialisasi kepada masyarakat tentang kewirausahaan. Pengetahuan kewirausahaan mendukung nilai-nilai wirausaha bagi seseorang, sehingga diharapkan menumbuhkan jiwa usaha untuk berwirausaha. Permasalahan yang ditemukan dalam masyarakat Nagari Sungai Pinang untuk memuali sebuah usaha adalah masalah kepercayaan antara sesama warga dan ketidakmampuan 
pengelolaan usaha. Dalam diskusi yang berlangsung pada saat kegiatan pengabdian kepada masyarakat dilakukan ditekankan besarnya pengaruh kepercayaan dalam kelompok dan pentingnya perana pemimpin dalam memanage usaha yang akan dilakukan. Pada kegiatan pengabdian kepada masyarakat selanjutnya direncanakan akan membuat Business Plan (Rencana Usaha) yang bermanfaat sebagai cetak biru usaha dan bisa dimanfaatkan untuk mencari investor.

\section{Daftar Pustaka}

Alfianto, E. A., Sos, S., \& AB, M. (2012). Kewirausahaan: Sebuah Kajian Pengabdian Kepada Masyarakat. Heritage, 1(2), 33-42.

Buang, Nor Aishah. (2013). Pendidikan Keusahawanan. Malaysia: UKM

Dulkiah, Moh. Trust Building Pedagang Kain Dan Pakaian di Cirebon. Bandung: UIN Sunan Gunung Djati

Fatimah, Siti, Dkk. (2017). Laporan Akhir: Pemberdayaan Desa Binaan Sungai Nyalo Kecamatan XI Tarusan Kabupaten Pesisir Selatan tahun 2017. Laporan Pengabdian kepada Masyarakat. Universitas Negeri Padang

Fitriani, E., \& Selinaswati, S. (2019). Pemanfaatan Potensi Budaya Lokal Dalam Pembangunan Ekowisata. ABDI: Jurnal Pengabdian dan Pemberdayaan Masyarakat, 1(1), 1-7.

Fitriani, E., Selinaswati, S., \& Mardhiah, D. (2018). Partisipasi Masyarakat Dalam Pembangunan Ekowisata Sungai Pinang. SOCIUS, 4(2), 83-96.

Fukuyama, F. (1995). Trust: The Social Virtues and The Creation of Prosperity. New York: A Division of Simon \& Schuster Inc. http://digilib.uinsgd.ac.id

Prakoso, Johanes Randy. (2015). Mengenal Sungai Pinang, Tempat Pertemuan Cinta Pait \& Jennifer. https://travel.detik.com/domestic-destination/d-2989526

Wijayanto, A. (2013). Pengaruh Karakteristik Wirausahawan Terhadap Tingkat Keberhasilan Usaha: Studi Pada Sentra Usaha Kecil Pengasapan Ikan Di Krobokan Semarang. Jurnal Ilmu Sosial, 12(1), 16-28.

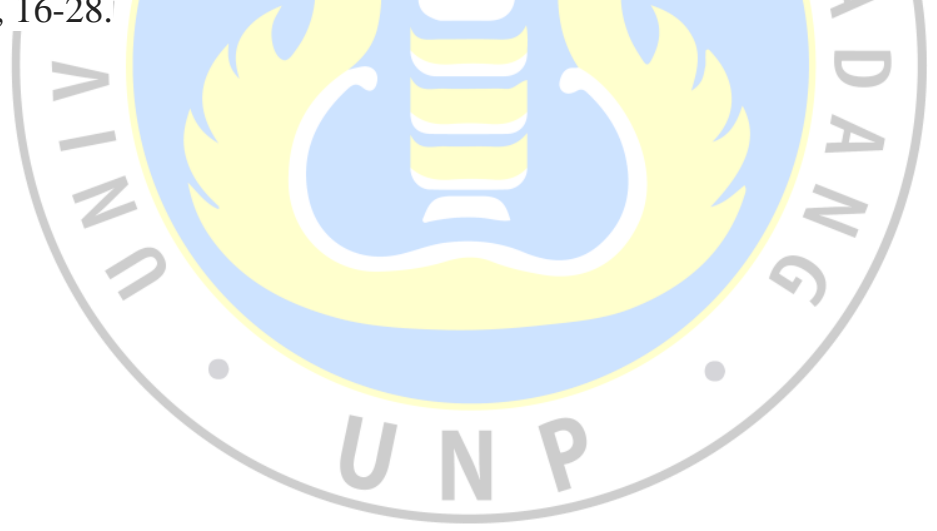

